INDEPENDENT JOURNAL OF MANAGEMENT \& PRODUCTION (IJM\&P)

http://www.ijmp.jor.br

v. 5 , n. 4 , October - December 2014

ISSN: 2236-269X

DOI: 10.14807/ijmp.v5i4.216

\title{
OPERATIONS MANAGEMENT TOOLS IN BRAZILIAN SMALL COMPANIES
}

Tonny Kerley de Alencar Rodrigues Federal University of Rio de Janeiro (Coppead), Brazil

E-mail: tonny.rodrigues@coppead.ufrj.br

Átila de Melo Lira Universidade Paulista, Brazil E-mail: atilalira@hotmail.com

Irenilza de Alencar Naas Universidade Paulista, Brazil E-mail: irenilza@gmail.com

Submission: 01/04/2014

Revision: $17 / 04 / 2014$

\section{ABSTRACT}

Accept: $30 / 04 / 2014$

This research has the objective was to characterize the small Brazilian companies about the knowledge of operations management tools that help in improving the administrative process for these organizations. For that we chose a more positivist strand which values quantitative aspects. The research was explanatory, applied and can be classified as survey. The population for this study is composed by Brazilian small enterprises are characterized by having a lower or equal to $R \$$ $3,600,000$ (approximately $1,800,000$ dollars) gross annual income. To collect information regarding the diagnosis of the degree of knowledge of small entrepreneurs, it was used a structured questionnaire using gradual tracks in identification of the respondent and the firm. It was found that the majority of managers interviewed small enterprises does not use the operations management tools, because they do not know such tools or have no need for their use in their companies.

Keywords: Small companies, Brazilian companies, Operations management tools.

Contributors and Supporting Agencies: Capes, $\mathrm{CNPq}$ and Associação Teresinense de Ensino. 


\section{INTRODUCTION}

Small businesses are in accordance with Complementary Law No. 123 of December 14, 2006, the individual limited liability companies, simple partnerships, business corporations and businessman who plays professionally organized to produce goods and services that get economic activity or an annual gross income equal to or less than $R \$ 3,600,000$ (approximately one million eight hundred dollars) (BRAZIL, 2006).

In designing Santos, Silva and Neves (2011) claim that the world these companies form a production system that allows the dilution of the economy in thousands of projects. In the Brazilian case, these authors postulate that the small companies play an important socioeconomic role in generating income, offering jobs and strengthen the economy.

Small enterprises form a production system worldwide that enables, on the basis of a society, the dilution of the economy in thousands of projects. Highlighting the Brazilian case, the small enterprises are important in generating income, the provision of jobs and strengthen the economy. Therefore, this segment has an important social and economic role as a center for the creation and distribution of wealth, decisive in generating jobs and economic development (SANTOS et al., 2011).

Borges et al. (2012) show that due to the importance of local businesses, small enterprises, it is necessary to isolate aspects of the same failure to understand the phenomena that influence the continuity of business. Since knowledge of these causes is important to create instruments to minimize the levels of discontinuation of these companies.

Due to the importance of local businesses as a source of funds is what is needed to isolate the causative aspects of success or failure, to understand all phenomena that directly or indirectly influence the continuity, informing the business owner the best way to go in managing their businesses to achieve effectiveness and success. Knowledge of the causes is indeed important condition for the possible creation of instruments to minimize the rates of discontinuation of businesses, such as policies to encourage the creation and survival of these (BORGES et al., 2012). 
DOI: 10.14807/ijmp.v5i4.216

This research appeared on the following question: what degree of knowledge of the small Brazilian businessmen about operations management tools? Was taken as the main assumption in this question that business owners have poorly qualified knowledge about these tools. The objective was to characterize the small Brazilian companies about the knowledge of operations management tools that help in improving the administrative process for these organizations.

\section{THE CURRENT SCENARIO OF SMALL BRAZILIAN COMPANIES}

The current economic context is marked by competitiveness between organizations. The relentless pursuit of profit leads to large corporations - with their lush technological infrastructure and its highly trained staff - to increase profitability in its industry and then increase its market share in this sector, thus removing the small enterprises.

The period of import substitution, through the emergence of the phenomenon of globalization, attempts to stabilize the Brazilian economy and trade liberalization has meant that large corporations were pressured to adopt the international standards of competitiveness, reducing costs to ensure global standard competition (SOUZA et al., 2007).

This caused many small enterprises to raise their difficulties to compete with these big corporations. Thus, many who wish to open their own business as a way to earn a living began to run into problems such as the lack of technical and scientific knowledge, the operation of the planning and implementation of management tools and the lack of proposals for assistance to these organizations (RIBEIRO, 2011).

According to the Brazilian Institute of Geography and Statistics - IBGE (2011) and Annual Social Information - RAIS (2011), small enterprises correspond to most Brazilian companies and employ the majority of the population, yet they account for a small share of GDP and nearly half of them do not pass the first years of life. As Borges et al. (2012, p.21), "The high mortality rate of businesses is a problem that undermines economic growth. There is a susceptibility to the closure of businesses, especially in the early years of existence".

In this sense, one of the main factors contributing to the high mortality of these organizations is the lack of management tools applications. The current literature on the subject points out that this fact is because the managers of these organizations, 
DOI: 10.14807/ijmp.v5i4.216

largely lack the scientific knowledge about these tools (RIBEIRO, 2011; SANTOS et al., 2012; SANTOS et al., 2011; TACHIZAWA; POZO, 2007). They manage the only empirical knowledge, or common sense, that they call "practical". Combine this practice to the theory can be a way these organizations achieve survival.

\section{BRAZILIAN SMALL COMPANIES ON OPERATIONS MANAGEMENT TOOLS}

With regard to the productive aspect, identifying the right kind of productive management to be used by an small enterprises can be a difficult and complex task. Since investment in a production suitable for small business high growth or growth in fixed rates for a considerable period of time model, the correct choice of the production model is critical to the profitability of micro and small business in the short and long-term (RIBEIRO, 2011).

Research on the selection and implementation of management tools for productive environments has been extensive. What is perceived to deploy these management tools is that the smaller the business unit, the greater the positive effect and its ability to transform (SANTOS et al., 2012). Therefore it can be stated that these tools are indispensable for the small companies.

Small enterprises, which consist of productive units that seek to add value continuously, can reduce the difficulties in realizing the benefits of many of these management tools in its production process, while in which they are being applied (SOUZA et al., 2007).

The production and control of the production process of these organizations, though less than the automated production of large corporations, become much more robust in competitiveness with the use of these management tools (SANTOS et al., 2011).

The choice of the productive structure is one of the most important decisions faced by the management of small enterprises. While there may be studies that engage the decision of the production structure and offers more empirical work with large public companies, this study also discusses the tools of operations management to small companies. 
DOI: 10.14807/ijmp.v5i4.216

\section{METHODOLOGY}

In research question we chose a more positivist strand which values quantitative aspects (KUHN, 1997). As Vergara (2006), the methodology can be categorized as to the purposes and on the means. As for the purpose, the research can be exploratory and applied. As for the means, the research can be classified as survey.

The population for this study is composed by Brazilian small enterprises are characterized by having a lower or equal to $R \$ 3.600,000$ (approximately $1,800.000$ dollars) gross annual income. They amount to about 5.786 .696 business establishments, according to IBGE (2011).

Regarding the sample, it was random stratified where "n" calculated was 664 small businesses at a confidence level of $99 \%$ and a sampling error of $5 \%$. The "n" observed, for example the amount of small enterprises who answered the questionnaire proposed was 800 , thus reducing a little more sampling error, although it has not reached a sampling error of $3 \%$, which would require a sample of 1.843 questionários. Thus it is noteworthy that the absolute majority of research in the area of Social Sciences uses the sampling error of $5 \%$.

According to IBGE (2011), through its management of research, stratification of small Brazilian enterprises has the following format: $1.3 \%$ in the northern region, $14.3 \%$ in the Northeast, $55.5 \%$ in southeast, $22.4 \%$ in the south and $6.5 \%$ in the Midwest. Thus, the sample is very close to the percentages of these percentages for each region, proceeding just rounding them.

To obtain these samples as close to these percentages, the researcher was counting the questionnaires answered by geopolitical region of the country. As you could be the desired percentage, going to disregard or not count most of the responses coming from that region. This procedure allowed the stratification of the sample.

To collect information regarding the diagnosis of the degree of knowledge of small entrepreneurs, a structured questionnaire using gradual tracks in identification of the respondent and the firm (such as age groups, marital status, length of business and geographic region was used business location) and a Likert type scale which is related to the knowledge of small entrepreneurs on operations management 
DOI: 10.14807/ijmp.v5i4.216

tools, where the researcher was able to deduce the main difficulties encountered by respondents in the administrative process for these organizations and the level of skilled knowledge operations management tools of small enterprises. The scale had the following configuration: a) Strongly agree; b) Agree in parts; c) Neither agree nor disagree; d) disagree in parts; e) Strongly disagree.

The questionnaire was filed in Google Docs (Internet tool that provides free filing of a questionnaire), and sent to the SEBRAE of all states of the federation, secretaries of finance, development and farm all the states and capitals of the country, departments management, economics and accounting in various Brazilian federal universities with a disclosure requirement for small entrepreneurs. Furthermore, the researcher sent the questionnaire to your bank emails of small business owners across the country.

The pretest of the instrument was performed with some businessmen database researcher who agreed to contribute to the development and structuring of it. Data collection occurred from November 2011 to March 2012. Initially the researcher personally visited some offices SEBRAE (Brazilian Service to Support Small Business), SESI (Social Service of Industry) and SESC (Social Service of Commerce) and some departments of farm some municipalities in the North and Northeast of Brazil to promote research and seek cooperation in sending the same link of the instrument and the awareness of entrepreneurs to reply the questionnaire.

The data relating to the questionnaire were analyzed with the help of SPSS (Statistical Package for Social Science). Through breeding techniques could be identified as the organizational structure and the type of manager that applies more or less applies operations management tools, as well as which ones that have better financial results. Also, was provided at the end of the analysis of the results, a set of operations management tools found in the literature of administrative sciences for the best management of these small enterprises.

The selection methodology and exemplification of management tools was made compatible with the defined objectives and design management as a scientific and technical process of applying scientific knowledge to seek survival and/or growth of small enterprises. 
DOI: 10.14807/ijmp.v5i4.216

\section{RESULTS AND DISCUSSION}

In questioning the managers of the companies if the current physical space in the company was sufficient for all the activities he wanted to accomplish, it was noted that in relation to this premise: $46.18 \%$ strongly agreed, $24.41 \%$ disagreed completely, $11,18 \%$ neither agreed nor disagreed, $11.18 \%$ agreed shares, $6.76 \%$ disagreed in parts, and $0.29 \%$ no opinion.

The premise: know the correct time and the correct amount of supplies to be purchased per month by my company not to miss or leftover goods, it was found among the managers who: $52.94 \%$ strongly agreed, $14.12 \%$ agreed parts; $13.24 \%$ disagreed completely, or $12.06 \%$ agreed nor disagreed, $7.06 \%$ disagreed in parts, and $0.58 \%$ prefer not to answer.

As for the statement: Before performing the tasks of my business I make a plan of action to indicate who will do something when going to do, where to go, how much will be spent and how it is performed, it was noted between managers which: $47.94 \%$ strongly agreed, $24.41 \%$ disagreed totally, $12.94 \%$ agreed in parts; $8.53 \%$ or agreed nor disagreed, $5.29 \%$ disagreed in parts, and $0.89 \%$ prefer not respond.

As to assert that he knew the cause of all the problems of the company, for example, the root of the problems, managers: $62.35 \%$ fully agreed; $12.94 \%$ totally disagreed; $12.35 \%$ agreed parties; $7.94 \%$ neither agreed nor disagreed, $3.24 \%$ disagreed in parts, and $1.18 \%$ prefer not to answer.

When the managers said that among the numerous tasks they had to perform day-to-day we knew distinguish those with greater severity, urgency and relevance, which are realized: $57.65 \%$ strongly agreed, $21.76 \%$ disagreed utterly: $7.94 \%$ parties agreed, $7.06 \%$ neither agreed nor disagreed, $3.24 \%$ prefer not to answer, and $2.35 \%$ disagreed in part.

With respect to knowing exactly towns or places that the company should sell its products in order to obtain higher gains, it was found that managers: $43.82 \%$ strongly agreed, $27.94 \%$ disagreed completely, or $11.47 \%$ agreed nor disagreed, $10.29 \%$ agreed in parts; $6.18 \%$ disagreed in parts, and $0.30 \%$ prefer not to answer.

Forward to the following assertion: if the company wants to open a new branch or a new point of sale, I'll know where in higher return, it was noted that managers: 
DOI: 10.14807/ijmp.v5i4.216

$50.59 \%$ strongly agreed, $24.41 \%$ disagreed completely; $11,76 \%$ agreed in parts; $8.53 \%$ neither agreed nor disagreed, $4.18 \%$ disagreed in parts, and $0.53 \%$ prefer not to answer.

How to know all the costs (as storage, insurance, tax, depreciation, freight, etc.) that the company could have if he wanted to deliver the product to the customer, it was perceived that managers face this assertion: $49.71 \%$ agreed totally, totally $23.82 \%$ disagreed, $10.59 \%$ agreed parties; $10.59 \%$ neither agreed nor disagreed, $5.00 \%$ disagreed in parts, and $0.29 \%$ prefer not to answer.

Regarding the knowledge of the time the company takes to deliver a product to the customer, it was found that managers: $59.71 \%$ strongly agreed, $16.47 \%$ disagreed completely, $9.41 \%$ agreed in parts; $8.53 \%$ neither agreed nor disagreed, $4.71 \%$ disagreed in parts, and $1.17 \%$ prefer not to answer.

How to know the quantity of products that have been returned because they are damaged, faulty or delays, it was perceived among the managers who: $45.59 \%$ strongly agreed, $27.94 \%$ disagreed completely; parties agreed to $9.71 \%, 9.41 \%$ neither agreed nor disagreed, $6.18 \%$ disagreed in parts, and $1.17 \%$ prefer not to answer.

How to know the amount of requests that were made by customers who were satisfied, fulfilled within or without errors in the collection, it was noted, among managers who: $58.53 \%$ strongly agreed, $17.65 \%$ disagreed completely; $10.29 \%$ agreed in parts; $9.41 \%$ neither agreed nor disagreed, $2.94 \%$ disagreed in parts, and $1.18 \%$ prefer not to answer.

Forward the claim to know the value (in dollars) of stock in the company that had the day of the survey, it was found among the managers who: $51.76 \%$ strongly agreed, $20.00 \%$ strongly disagreed, $14.71 \%$ neither agreed nor disagreed, $6.76 \%$ disagreed parts; parties agreed to $6.47 \%$, and $0.30 \%$ prefer not to answer.

\section{CONCLUSION}

Regarding affirmative scale of knowledge, the answer choice that had the highest incidence was the "strongly disagree" ( $55 \%$ on average), may show that the majority of managers interviewed small enterprises does not use the operations 
DOI: 10.14807/ijmp.v5i4.216

management tools. Is because they do not know such tools or have no need for their use in their companies.

Thus, it is suggested that further studies be carried out in different segments as small Brazilian companies to identify the needs of operations management tools according to the peculiarities of each type of company. Furthermore, it is suggested that the organs of support and encouragement can stimulate the use of such tools to enable economic and financial growth of these organizations and therefore their survival in the highly globalized market in which they live.

\section{REFERENCES}

BORGES, G. F. et al (2012) Descontinuidade de empresas: um estudo sob a ótica dos contadores na cidade de São João Del-Rei (MG) Revista Mineira de Contabilidade, v. 13, n. 45, p. 21-28.

IBGE (2011) Instituto Brasileiro de Geografia e Estatística. Pesquisa nacional por amostra de domicílios. Available: http:// www.ibge.gov.br. Accessed at: 25/09/2011. KUHN, T. S. (1997) A estrutura das revoluções científicas. São Paulo: Perspectiva.

RAIS (2011) Relação Anual de Informações Sociais do Ministério do Trabalho e Emprego. Available: http://www. mte.gov.br. Accessed at: 25/09/2011.

RIBEIRO, D. A. S. (2011) Planejamento estratégico e o processo decisório em micro e pequenas empresas. Monografia (Graduação em Administração). Brasília: abril / UnB. Available:

http://bdm.bce.unb.br/bitstream/10483/2848/6/2011_DanielAndreSilvaRibeiro.pdf. Accessed at: 25/09/2011

SANTOS, G. M. et al (2011) Risco de sobrevivência de micro e pequenas empresas comerciais. Revista de Contabilidade e Organizações, v. 5, n. 11, p. 107-124.

SANTOS, M. B. (2012) New forms of work organization in micro and small enterprises. Available: http://mpra.ub.uni-muenchen.de/ 35700/1/MPRA_paper_35700.pdf. Accessed at: 02/02/2012.

SOUZA, J. H. et al(2007) As origens da pequena empresa no Brasil. Revista de Micro e Pequena Empresa, v. 1, n. 1,p. 53-65.

TACHIZAWA, T.; POZO, H. (2007) Gestão de recursos humanos em micro e pequenas empresas: um enfoque de gestão ambiental e responsabilidade social para seu crescimento. Revista da Micro e Pequena Empresa, v. 1, n. 1, p. 04-23.

VERGARA, S. C. (2006) Projetos e relatórios de pesquisa em administração. São Paulo: Atlas. 